\title{
KONSISTENSI PEDAGANG LESEHAN KASEPUHAN CIREBON TERHADAP DAYA SAING WARUNG MAKAN MODEREN
}

\author{
Afif Muamar, Ubaidillah dan Hafizh Al-Haq Hasanudin \\ Fakultas Syari'ah dan Ekonomi Islam \\ Institut Agama Islam Negeri Syekh Nurjati Cirebon \\ e-mail: afifmuamar85@gmail.com,ubaidillah_firly@yahoo.com \\ dan hafizhalhaqhasanudin@gmail.com
}

\begin{abstract}
Given that the development of restaurants stalls in the city of Cirebon (along the strategic streets of Cirebon City) is very rapid and there are still many opportunities to enter the culinary business market. So business actors are demanded to improve the quality of service and marketing communications, so have a competitive advantage against similar businesses. The method used by researchers in this research is descriptive qualitative method. The result of this research is the consistency of lesehean trader in maintaining the taste and the price of the products it creates is influenced by intristic factor of trader and extrinsic trader, the merchant's intrinsic factor is related to the idea of determining the product being sold, while the trader's extrinsic factor is related to the consistency of the trader in create product recipes. The competitiveness of pedagagang lesehan Era with restaurant in Cirebon City is good because in order to compete with traders who already have a permanent place, traders lesehan in the elderly do business competition with normal that is by strengthening market share, connecting with environment, improve performance, and enforce a favorable position.
\end{abstract}

Keywords: Consistency, Competitivenes, and Marketing Communications.

\begin{abstract}
Abstrak
Mengingat bahwa perkembangan usaha rumah makan di wilayah Kota Cirebon (sepanjang jalan-jalan strategis di Kota Cirebon) sangat pesat dan masih banyaknya peluang untuk memasuki pasar bisnis kuliner tersebut. Maka pelaku usaha di tuntut untuk meningkatkan kualitas pelayanan dan komunikasi pemasaran, sehingga memiliki keunggulan bersaing terhadap usaha yang sejenis. Metode yang digunakan peneliti dalam penelitian ini adalah metode kualitatif deskriptif. Hasil penelitian yang didapat dalam penelitian ini adalah konsistensi pedagang lesehean kesepuhan dalam mempertahankan cita rasa dan harga produk yang diciptakannya dipengaruhi oleh faktor intristik pedagang dan ekstrinsik pedagang, faktor instrinstik pedagang berkaitan dengan ide penentuan produk yang dijual, sementara faktor ekstrinsik pedagang berkaitan dengan konsistensi pedagang dalam membuat resep produk. Daya saing pedagagang lesehan Kesepuhan dengan rumah makan di Kota Cirebon terbilang baik karena demi untuk dapat bersaing dengan pedagang yang sudah memiliki tempat permanen, pedagang lesehan di kesepuhan melakukan persaingan usaha dengan normal yaitu dengan cara memperkokoh pangsa pasar, menghubungkan dengan lingkungan, meningkatkan kinerja,dan menegakan posisi yang menguntungkan.
\end{abstract}

Kata Kunci: Konsistensi, Daya Saing, dan Komunikasi Pemasaran. 


\section{PENDAHULUAN}

Otonomi daerah berpengaruh terhadap pertumbuhan ekonomi suatu daerah karena memberikan kebebasan kepada pemerintah daerah untuk membuat rencana keuangannya sendiri dan membuat kebijakan-kebijakan yang dapat berpengaruh pada kemajuan daerahnya. Pertumbuhan ekonomi mendorong pemerintah daerah untuk melakukan pembangunan ekonomi dengan mengelola sumber daya yang ada dan membentuk suatu pola kemitraan dengan masyarakat untuk menciptakan lapangan pekerjaan baru yang akan mempengaruhi perkembangan kegiatan ekonomi dalam daerah tersebut. ${ }^{{ }^{1}}$

Persaingan yang ketat dalam bidang bisnis kuliner khususnya di Kota Cirebon, juga disebabkan semakinbanyaknya usaha kuliner yang menyajikan berbagai variasi makanan, bahkan menu makanan luar Negeri yang memasuki pasar domestic. Masuknya bisnis kuliner yang menyajikan menu masakan luar negri seperti masakan Jepang, China atau India atau Amerika dan negeri-negeri Eropa dewasa ini di kelola secara professional. Hal ini menjadi pesaing bagi usaha kuliner lesehan, sehingga perlu dikelola secara professional agar mampu bersaing dengan rumah makan dalam melayani konsumen.

Salah satu tujuan konsumen masuk ke dalam rumah makan disamping hendak menghilangkan rasa lapar juga mengharap mendapatkan hiburan dari suasana yang nyaman dan santai disela rutinitas kegiatan sehari-hari. Keadaan emosional atau suasana hati bisa memotivasi keinginan konsumen untuk datang dan mencoba menu makan. Sebagai konsekuensinya, pedagang lesehan yang semula dikelola secara tradisional, di tuntut agar semakin inovatif, dinamis dan kompetitif.

\footnotetext{
${ }^{1}$ Mudrajat Kuncoro, Otonomi dan Pembangunan Daerah: Reformasi Perencanaan, Strategi, dan Peluang (Jakarta, Penerbit Erlangga, 2004), 23.
}

Untuk itu maka penulis merasa perlu untuk mengkaji lebih dalam lagi mengenai bagaimana konsistensi pedagang lesehan kasepuhan dalam mempertahankan cita rasa produk dan harganya? Dan bagaimana konsistensi pedagang lesehan kasepuhan terhadap daya saing rumah makan di Kota Cirebon?

\section{LITERATURE REVIEW}

Untuk menghindari plagiarisme maka penulis merasa perlu mencantumkan penelitian-penelitian terdahulu sebagai bentuk apresiasi karya tulis orang lain. Meskipun demikian, nampaknya belum ditemukan penelitian yang secara spesifik membahasa tentang konsistensi pedagang lesehan kasepuhan Cirebon. Berikut beberapa karya yang terdokumentasikan terkait permasalahan yang dikaji, yaitu pertama, penelitian Suhartanto dan Nuralia, "Citra Supermarket: Pengaruhnya terhadap Perilaku Konsumen". Dalam penelitian ini, dinyatakan bahwa dengan semakin banyak warung atau rumah makan yang bervariasi dan mudah di jumpai di berbagai tempat strategis di Kota Cirebon, maka keberadaan rumah makan dan bisnis kuliner sejenis dengan pengelolaan yang representative di tengah-tengah masyarakat menjadi semakin penting. Hal ini disebabkan selain karena adanya perubahan cara pandang konsep terhadap rumah makan yang cenderung formal itu, masyarakat dewasa ini suka mencoba hal-hal yang baru dari sebuah rumah makan. Citra rumah makan mempunyai enam dimensi, yaitu lokasi usaha, keragaman menu, harga iklan dan promosi penjualan, personel dan pelayanan yang di bangun oleh tiga dimensi utama, yaitu dimensi kualitas produk, dimensi harga dan dimensi suasana. ${ }^{2}$

Kedua, penelitian Slamet Santoso, "Kemampuan Bertahan pedagang warung

\footnotetext{
${ }^{2}$ Suhartanto dan Nuralia, "Citra Supermarket: Pengaruhnya terhadap Perilaku Konsumen", Jurnal Kajian Bisnis, No. 23 (Agustus, 2001): 56.
} 
HIK di Kota Ponorogo". Penelitian ini menekankan bahwa sampai dengan tahun 2006, jumlah pedagang warung hik tersebut mengalami peningkatan, yaitu lebih dari 20 (dua puluh) pedagang yang telah tersebar di kota Ponorogo. Kehadiran pedagang warung hik tersebut juga mendorong beberapa masyarakat Ponorogo untuk membuka usaha sejenis, dan sering disebut warung kopi lesehan. Dengan demikian, pedagang warung hik di samping harus mampu bersaing dengan sesame pedagang warung hik (sesama pedagang pendatang) juga harus mampu bersaing dengan warung kopi lesehan. ${ }^{3}$

Berdasarkan pemaparan penelitian terdahulu di atas, penelitian ini memiliki perbedaan yang signifikan, terutama dalam objek-objek yang diteliti. Oleh karena itu, berbeda dengan penelitian terdahulu, pada kali ini penelitian yang akan dilakukan yaitu memfokuskan praktik pedagang di sekitar kasepuhan Cirebon tetap konsisten dalam menjaga cita rasa produk dan harganya. Hal inilah yang membedakan penelitian kali ini dengan penelitain-penelitian sebelumnya.

\section{METODOLOGI PENELITIAN}

Adapun yang akan dijadikan lokasi penelitian adalah di sekitar Keraton Kasepuhan Cirebon. J1. Kasepuhan No. 43, Kelurahan Kasepuhan, Kecamatan Lemahwungkuk, Kota Cirebon Jawa Barat. Dalam hal ini jenias penelitian yang akan di gunakan oleh penelitian adalah kualitatif. Kualitatif data termasuk non-numerica, seperti mendeskripsikan tindakan atau isi dari respon orang-orang terhadap pertanyaan wawancara, observasi, study dokumen dan study pustaka tersebut, yang kemudian di analisa dan hasilnya di simpulkan sebagai hasil penelitian.

Menurut Suginono teknik pengumpulan data merupakan langkah yang

\footnotetext{
${ }^{3}$ Slamet Santoso, "Kemampuan Bertahan Pedagang Warung HIK di Kota Ponorogo", Skripsi (Ponorogo: Fakultas Ekonomi Universitas Muhammadiyah, 2006)
}

paling strategis dalam penelitian, karena tujuan utama dari penelitian adalah mendapatkan data. Ada dua jenis data yang dapat di ambil oleh peneliti yaitu Sumber Data Primer dan Sumber Data Sekunder. ${ }^{4}$

Dalam penelitian kualitatif, sebelum memasuki analisis lapangan perlu di lakukan data terhadap hasil observasi awal data sekunder yang akan di gunakan untuk memastikan fokus penelitian. Tapi fokus penelitian ini hanya untuk sementara waktu. Menurut HB. Sutopo mengatakan, bahwa dalam model analisis ini, tiga komponen analisisnya yaitu reduksi data, dan sajian data, dan penarikan kesimpulan atau verifikasi, aktifitasnya dilakukan dalam bentuk interaktif dengan proses pengumpulan data sebagai suatu proses yang berlanjut, berulang, dan terus menerus sehingga membentuk sebuah siklus. ${ }^{5}$

Dalam penelitian ini metode pengumpulan data yang digunakan oleh peneliti adalah observasi dan wawancara. Observasi merupakan teknik atau cara mengumpulkan data dengan mengadakan pengamatan terhadap kegiatan yang sedang berlangsung.

Dalam metode observasi ini peneliti mengetahui secara langsung dan jelas terhadap apa yang terjadi dilapangan dengan cara mengumpulkan data-data berupa struktur organisasi dan juga job desk melalui kontak secara langsung dengan obyek yaitu Pedagan Lesehan Kasepuhan di Kota Cirebon.

Wawancara merupakan pertemuan dua orang untuk bertukar informasi dan ide melalui tanya jawab, sehingga dapat dikonstruksikan makna dalam suatu topik tertentu. ${ }^{6}$

\footnotetext{
${ }^{4}$ Sugiono, Metodologi Penelitian Bisnis (Bandung: Alfabeta, 2013), 24.

${ }^{5}$ HB. Sutopo, Metodologi Penelitian Kualitatif: Dasar Teori dan Terapannya dalam Penelitian (Surakarta: Universitas Sebelas Maret, 2006), 9. 317.
} 
Teknik wawancara yang peneliti gunakan dalam penelitian kali ini yaitu dengan cara wawancara tak berstruktur. Wawancara tak berstruktur adalah teknik wawancara di mana pewawancara tidak menggunakan daftar pertanyaan atau daftar isian sebagai penuntun selama dalam proses wawancara. $^{7}$

Metode ini mencakup cara yang digunakan untuk suatu tujuan tertentu, mencoba mendapatkan keterangan atau pendapat lisan secara langsung dari responden atau informan. Adapun yang diwawancarai adalah para pelaku usaha atau pedagang di sekitar Kasepuhan Kota Cirebon.

Metode penelitian yang akan penulis gunakan adalah dengan metode penelitian kualitatif, yaitu suatu metode atau penelusuran untuk mengeksplorasi dan memahami suatu gejala sentral. Informasi data yang di cari dalam metode penelitian ini dapat berupa kata atau teks. Data yang berupa kata-kata atau teks tersebut kemudian dianalisis, dan hasil analisis itu dapat berupa penggambaran atau deskripsi atau dapat pula dalam bentuk tema-tema, sehingga akan diperoleh kesimpulan dari

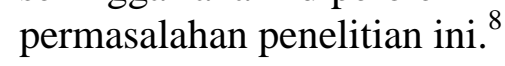

Analisis data dalam penelitian kualitatif dilakukan sejak sebelum memasuki lapangan, selama di lapangan, dan setelah di lapangan. Analisis data menjadi pegangan bagi penelitian selanjutnya sampai jika mungkin, teori yang "grounded". Namun dalam penelitian kualitatif, analisis data lebih difokuskan selama proses di lapangan bersamaan dengan pengumpulan data. ${ }^{9}$

\footnotetext{
${ }^{7}$ Iqbal Hasan, Pokok-pokok Materi Metodologi Penelitian dan Aplikasinya (Bogor: Ghalia Indonesia, 2002), 85. Lihat juga Sugiono, Metodologi Penelitian Bisnis, 319-322.

${ }^{8}$ JR. Raco, Metode Penelitian Kualitatif, Jenis, Karakteristik dan Keunggulannya (Jakarta: PT. Grasindo, 2010), 65.

245.
}

\section{KONSEP DASAR}

Konsistensi Pedagang dan Daya Saing

Konsistensi menurut KBBI (Kamus Besar Bahasa Indoneisa) bermaksud ketetapan dan kemantapan dalam bertindak. ${ }^{10}$ Adapun menurut Ariantokonsistensi adalah keteguhan hati terhadap tujuan dan usaha atau pengembangan yang takberkesudahan. Ariantojuga menambahkan ada beberapa hal yang di butuhkan untuk menjaga konsistensi antara lain adalah motif, kesadaran dan introspeksi. ${ }^{11}$

Berdasarkan penjelasan di atas dapatlah kemudian dipahami bahwa konsistensi pada dasarnya merupakan sikap dari individu dalam menanggapi suatu hal tertentu yaitu sikap kemantapan dalam bertindak disertai dengan tujuan-tujuan yang terarah.

Sementara itu yang dimaksud dengan pedagang adalah orang yang menjalankan usaha dengan cara berjualan, baik berjualan dalam usaha kerajinan, atau usaha pertukangan kecil dan lain sebagainya. Pedagang juga bisa di artikan orang yang dengan modal relatif bervariasi yang berusaha di bidang produksi dan penjualan barang atau jasa-jasa untuk memenuhi kebutuhan kelompok masyarakat. $^{12}$

Setelah memahami pengertian konsistensi dan pedagang sebagaimana yang telah dipaparkan di atas maka dapatlah kemudian dipahami bahwa yang dimaksud konsitensi pedagang adalah keteguhan hati seorang pedagang dalam melaksanakan kegiatan jual beli terhadap tujuan usaha jual beli yang dijalaninya tanpa berkesudahan.

\footnotetext{
${ }^{10}$ Lihat https://kbbi.web.id/konsistensi. Diakses pada tanggal 19 Maret 2018.

${ }^{11}$ Tulus Arianto, "Struktur Kepemilikan, Profitablitas, Pertumbuhan Aktiva, dan Ukuran Perusahaan terhadap Struktur Modal pada Perusahaan Manufaktur", Jurnal Keuangan dan Perbankan, Vol. 12, No. 1 (2008).

${ }^{12}$ Fani Damayanti "Analisis Faktor-faktor yang Mempengaruhi Tinggi Rendahnya Pendapatan Pedagang Kaki Lima”, Skripsi (Surakarta: Fakultas Ekonomi Universitas Sebelas Maret, 2011), 64.
} 


\section{Faktor-faktor yang Mempengaruhi \\ Konsistensi Pedagang}

Dikarenakan konsistensi merupakan bagian dari sikap seseorang, maka sudah barang tentu faktor-faktor yang mempengaruhinya pun berhubungan dengan motivasi individu tersebut. Dengan demikian, maka ada dua hal yang dapat mempengaruhi konsistensi pedagang dalam mejajakan bisnis dagangannya yaitu karena adanya motiv internal dan motiv eksternal.

Menurut Wina Sanjaya bahwa motivasi dapat dibedakan menjadi dua macam yaitu ada yang muncul dari dalam diri individu atau motivasi intrinsik dan ada yang datang dari luar diri yang disebut motivasi ekstrinsik. ${ }^{13}$

a. Motivasi intrinsic

Motivasi intrinsik adalah motivmotiv yang menjadi aktif atau berfungsinya tidak perlu dirangsang dari luar, karena dalam diri setiap individu sudah ada dorongan untuk melakukan sesuatu. Motiv ini berkembang dengan sendirinya.

b. Motivasi ekstrinsik

Motivasi ekstrinsik adalah motivmotiv yang aktif dan berfungsi karena adanya perangsang dari luar diri individu. Motivasi ekstrinsik ini tidak timbul dan berkembang dengan sendirinya, melainkan selalu berdasarkan interaksi dengan situasi dan sesuatu yang terdapat di luar individu.

Adapun jenis motivasi menurut Sardiman AM. bahwa motivasi dilihat dari dasar pembentukannya. Motivasi ini terbagi menjadi dua ${ }^{14}$ :

a. Motiv-motiv bawaan, adalah motiv yang dibawa sejak lahir. Motiv ini sudah ada tanpa dipelajari. Misalnya dorongan

\footnotetext{
${ }^{13}$ Wina Sanjaya, Perencanaan dan Desain Sistem Pembelajaran (Jakarta: Kencana Prenada Media Group, 2008), 256.

${ }^{14}$ Sardiman AM., Interaksi dan Motivasi Belajar Mengajar (Jakarta: Raja Grafindo. Persada, 1996), 85-88.
}

untuk makan, minum, dan dorongan untuk bekerja.

b. Motiv-motiv yang dipelajari, maksudnya motiv yang timbul karena dipelajari. Misalnya dorongan untuk belajar ilmu pengetahuan.

Dalam kaitannya dengan konsistensi pedagang, tentu juga demikian konsistensi yang dilakukannya dipastikan dipengaruhi oleh dua faktor di atas yaitu faktor intristik dan faktor ekstristik, faktor instrinsik contohnya seperti hobi untuk melakukan konsistensi karena baginya konsistensi merupakan cirri khas pada darinya. Faktor ekstrinsik contohnya seperti adanya permintaan dari pelanggan untuk mempertahankan harga, cita rasa produk dan lain sebagainya karena pembeli merasa nyaman dalam menikmati produk yang diperjual belikan oleh pedagang.

\section{Daya Saing dalam Perdagangan}

Daya saing adalah konsep perbandingan kemampuan dan kinerja perusahaan, untuk menjual dan memasok barang dan atau jasa yang diberikan dalam pasar. Daya saing sebuah usaha dapat dicapai dari akumulasi daya saing strategis setiap perusahaan. Proses penciptaan nilai tambah (value added creation) berada pada lingkup perusahaan. ${ }^{15}$

Daya saing adalah kemampuan untuk menunjukkan hasil yang lebih baik, lebih cepat atau lebih bermakna. Kemampuan yang dimaksud adalah (1) kemampuan memperkokoh pangsa pasarnya, (2) kemampuan menghubungkan dengan lingkungannya, (3) kemampuan meningkatkan kinerja tanpa henti, (4) kemampuan menegakkan posisi yang menguntungkan. ${ }^{16}$

Daya saing adalah produktivitas yang didefinisikan sebagai output yang di hasilkan oleh tenaga kerja. Menurut World

\footnotetext{
${ }^{15}$ Mudrajat Kuncoro, Ekonomika Industri Indonesia: Menuju Negara Industri Baru 2030? (Yogjakarta: Penerbit Andi, 2007), 82.

${ }^{16}$ Lihat Peraturan Menteri Pendidikan Nasional No. 41 Tahun 2007 tentang Standar Proses
} 
Economic Forum, daya saing nasional adalah kemampuan perekonomian nasional untuk mencapai pertumbuhan ekonomi yang tinggi dan berkelanjutan. Daya saing ditentukan oleh keunggulan bersaing suatu perusahaan dan sangat bergantung pada tingkat sumber daya relatif yang dimilikinya atau biasa kita sebut keunggulan kompetitif. Selanjutnya, Porter menjelaskan pentingnya daya saing karena tiga hal yaitu (1) mendorong produktivitas dan meningkatkan kemampuan mandiri, (2) dapat meningkatkan kapasitas ekonomi, baik dalam konteks regional ekonomi maupun kuantitas pelaku ekonomi sehingga pertumbuhan ekonomi meningkat, (3) kepercayaan bahwa mekanisme pasar lebih menciptakan efisiensi. ${ }^{17}$

\section{Cara Menentukan Daya Saing}

Agar daya saing perdagangan atau kegiatan berdagang seseorang dalam menjajakan produk daganganya menjadi baik diperlukan penentuan daya saing. Sehingga dengan penentuan daya saing tersebut akan diperoleh manfaat yang baik bagi kemajuan usaha.

Menurut Porter ada tiga cara untuk dapat menentukan daya saing, yaitu (1) Keunggulan Biaya (Cost Leadership), (2) Pembedaan Produk (Differentiation), dan (3) Fokus (Focus). Adapun penjelasan dari tiap-tiap strategi penentuan daya saing tersebut adalah sebagai berikut ${ }^{18}$ :

a. Strategi Biaya Rendah (cost leadership)

Strategi Biaya Rendah (cost leadership) menekankan pada upaya memproduksi produk standar (sama dalam segala aspek) dengan biaya per unit yang sangat rendah. Produk ini (barang maupun jasa) biasanya ditujukan kepada konsumen yang relatif mudah terpengaruh oleh pergeseran harga (price

\footnotetext{
${ }^{17}$ Micel E. Porter, Competitive Advantage, Edisi 4 (Jakarta: PT. Indeks Kelompok Gramedia, 2001), 12-14.

${ }^{18}$ Fred R. David, Manajemen Strategis Konep (Jakarta: Salemba Empat, 2011), 145.
}

sensitive) atau menggunakan harga sebagai faktor penentu keputusan. ${ }^{19}$

Dari sisi perilaku pelanggan, strategi jenis ini amat sesuai dengan kebutuhan pelanggan yang termasuk dalam kategori perilaku lowinvolvement, ketika konsumen tidak terlalu peduli terhadap perbedaan merek, relatif tidak membutuhkan pembedaan produk, atau jika terdapat sejumlah besar konsumen memiliki kekuatan tawarmenawar yang signifikan.

Terutama dalam pasar komoditi, strategi ini tidak hanya membuat perusahaan mampu bertahan terhadap persaingan harga yang terjadi tetapi juga dapat menjadi pemimpin pasar (market leader) dalam menentukan harga dan memastikan tingkat keuntungan pasar yang tinggi (di atas rata-rata) dan stabil melalui cara-cara yang agresif dalam efisiensi dan kefektifan biaya. Sumber dari keefektifan biaya (cost effectiveness) ini bervariasi.Termasuk di dalamnya adalah pemanfaatan skala ekonomi (economies of scale), investasi dalam teknologi yang terbaik, sharing biaya dan pengetahuan dalam internal organisasi, dampak kurva pembelajaran dan pengalaman (learning and experience curve), optimasi kapasitas utilitas, dan akses yang baik terhadap bahan baku atau saluran distribusi. ${ }^{20}$

Untuk dapat menjalankan strategi biaya rendah, sebuah perusahaan harus mampu memenuhi persyaratan di dua bidang, yaitu sumber daya (resources) dan organisasi. Strategi ini hanya mungkin dijalankan jika dimiliki beberapa keunggulan di bidang sumber daya perusahaan, yaitu pemasaran produk, kreativitas dan bakat SDM, pengawasan yang ketat, riset pasar, distribusi yang kuat, ketrampilan kerja, Konsep, 145.
${ }^{20}$ Fred
Konsep, 146.
${ }^{19}$ Fred R. David, Manajemen Strategis 
serta biaya distribusi dan promosi rendah. Sedangkan dari bidang organisasi, perusahaan harus kuat dan mampu untuk melakukan: koordinasi antar fungsi manajemen yang terkait, merekrut tenaga yang berkemampuan tinggi, insentif berdasarkan target (alokasi insentif berbasis hasil).

b. Strategi Pembedaan Produk (differentiation)

Strategi Pembedaan Produk (differentiation), mendorong perusahaan untuk sanggup menemukan keunikan tersendiri dalam pasar yang jadi sasarannya. Keunikan produk (barang atau jasa) yang dikedepankan ini memungkinkan suatu perusahaan untuk menarik minat sebesar-besarnya dari konsumen potensialnya. ${ }^{21}$ Cara pembedaan produk bervariasi dari pasar ke pasar, tetapi berkaitan dengan sifat dan atribut fisik suatu produk atau pengalaman kepuasan (secara nyata maupun psikologis) yang didapat oleh konsumen dari produk tersebut. Berbagai kemudahan pemeliharaan, features tambahan, fleksibilitas, kenyamanan dan berbagai hal lainnya yang sulit ditiru lawan merupakan sedikit contoh dari diferensiasi. Strategi jenis ini biasa ditujukan kepada para konsumen potensial yang relatif tidak mengutamakan harga dalam pengambilan keputusannya.

Perlu diperhatikan bahwa terdapat berbagai tingkatan diferensiasi. Diferensiasi tidak memberikan jaminan terhadap keunggulan kompetitif, terutama jika produk-produk standar yang beredar telah (relatif) memenuhi kebutuhan konsumen atau jika kompetitor/pesaing dapat melakukan peniruan dengan cepat. Contoh penggunaan strategi ini secara tepat adalah pada produk barang yang bersifat

Konsep, 147. tahan lama (durable) dan sulit ditiru oleh pesaing.

Resiko lainnya dari strategi ini adalah jika perbedaan atau keunikan yang ditawarkan produk tersebut ternyata tidak dihargai (dianggap biasa) oleh konsumen. Jika hal ini terjadi, maka pesaing yang menawarkan produk standar dengan strategi biaya rendah akan sangat mudah merebut pasar. Oleh karenanya, dalam strategi jenis ini, kekuatan departemen Penelitian dan Pengembangan sangatlah berperan.

c. Strategi Fokus (Focus)

Strategi fokus digunakan untuk membangun keunggulan bersaing dalam suatu segmen pasar yang lebih sempit. Strategi jenis ini ditujukan untuk melayani kebutuhan konsumen yang jumlahnya relatif kecil dan dalam pengambilan keputusannya untuk membeli relatif tidak dipengaruhi oleh harga. ${ }^{22}$ Dalam pelaksanaannya terutama pada perusahaan skala menengah dan besar, strategi fokus diintegrasikan dengan salah satu dari dua strategi generik lainnya: strategi biaya rendahatau strategi pembedaan karakteristik produk.

Syarat bagi penerapan strategi ini adalah adanya besaran pasar yang cukup (market size), terdapat potensi pertumbuhan yang baik, dan tidak terlalu diperhatikan oleh pesaing dalam rangka mencapai keberhasilannya. Strategi ini akan menjadi lebih efektif jika konsumen membutuhkan suatu kekhasan tertentu yang tidak diminati oleh perusahaan pesaing. Biasanya perusahaan yang bergerak dengan strategi ini lebih berkonsentrasi pada suatu kelompok pasar tertentu, wilayah geografis tertentu, atau produk barang atau jasa tertentu dengan kemampuan memenuhi kebutuhan konsumen secara baik.

Menurut Michael Porter, hal-hal yang harus dikuasai atau dimiliki oleh

${ }^{22}$ Fred R. David, Manajemen Strategis Konsep, 148. 
setiap perusahaan untuk meningkatkan keunggulan kompetitif, ${ }^{23}$ yaitu:

1) Teknologi

2) Tingkat entrepreneurship yang tinggi

3) Tingkat efisiensi/produktivitas yang tinggi dalam proses produksi

4) Kualitas serta mutu yang baik dari barang yang dihasilkan

5) Promosi yang meluas dan agresif

6) Pelayanan teknisal maupun nonteknisal yangbaik (service after sale).

7) Tenaga kerja dengan tingkat keterampilan/pendidikan, etos kerja, kreativitas, serta motivasi yang tinggi

8) Skala ekonomis

9) Inovasi

10) Diferensiasi produk

11) Modal dan sarana serta prasarana lainnya yang cukup

12) Jaringan distribusi di dalam dan terutama di luar negeri yang baik dan well-organized/managed

13) Proses produksi yang dilakukan dengan sistem just-in-time (JIT).

\section{Pedagang, Perdagangan dan Lesehan}

Pedagang adalah orang yang menjalankan usaha dengan cara berjualan, baik berjualan dalam usaha kerajinan, atau usaha pertukangan kecil. Pedagang juga bisa di artikan orang yang dengan modal relatif bervariasi yang berusaha di bidang produksi dan penjualan barang atau jasa-jasa untuk memenuhi kebutuhan kelompok masyarakat. ${ }^{24}$

Adapun yang dimaksud dengan perdagangan adalah prihal yang berikatan dengan kegiatan dagang. ${ }^{25}$ Dengan demikian dapatlah dipahami bahwa perdagangan

\footnotetext{
${ }^{23}$ Tulus Tambunan, Perekonomian Indonesia: Teori dan Temuan Empiris (Jakarta: Ghalia Indonesia, 2001), 55.

${ }^{24}$ Fani Damayanti, "Analisis Faktor-faktor yang Mempengaruhi Tinggi Rendahnya Pendapatan Pedagang Kaki Lima", 63.

${ }^{25}$ Lihat https://kbbi.web.id/perdagangan. Diakses pada tanggal 19 Maret 2018.
}

adalah segala sesuatu yang berkaitan dengan kegiatan dagang, sementara yang dimaksud dengan pedagang adalah orang yang menjul atau menjajakan produk dagangannya.

Lesehan adalah suatu budaya dalam hal memperjualbelikan makanan atau sesuatu barang sembari duduk di tikar/lantai. Makanan atau barang yang diperjualbelikan turut digelar pada saat lesehan sehingga pengunjung bisa melihat dan memilihnya dengan santai. Budaya Lesehan yang sangat terkenal di Indonesia adalah di daerah Yogyakarta dan hal ini menjadi salah satu daya tarik tersendiri bagi wisatawan, baik dari dalam maupun luar negeri. ${ }^{26}$

\section{Unsur-unsur dalam Perdagangan}

Sebagai sebuah kegiatan ekonomi, perdagaagan didalamnya memuat unsurunsur pokok didalamnya, yaitu modal, pedagang, produk, dan pelanggan (Pembeli). Dalam kegiatan perdagangan ke empat unsur-unsur di atas tersebut saling berkaitan dan saling membutuhkan. Contohnya adanya harga tentu karena ada produk yang dijual, adanya aktifitas penjualan tentu karena ada modal, pembeli dan pedagang. Begitupun seterusnya ke empatnya saling berkaitan.

\section{Modal}

Apabila barang yang dijual belum diketahui oleh pembeli maka penjual harus memperkenalkan dulu atau membawa barangnya ke tempat pembeli. Untuk melaksanakan maksud tersebut diperlukan adanya sarana serta usaha, seperti: alat transport, tempat peragaan baik di dalam perusahaan maupuun diluar perusahaan, usaha promosi, dan sebagainya. Semua ini hanya dapat dilakukan apabila penjual memilik sejumlah modal untuk itu.

\footnotetext{
${ }^{26}$ Lihat https://kbi.web.id/lesehan. Diakses
} pada tanggal 19 Maret 2018. 


\section{Pedagang}

Pedagang adalah orang yang menjalankan usaha dengan cara berjualan, baik berjualan dalam usaha kerajinan, atau usaha pertukangan kecil.Pedagang juga bisa di artikan orang yang dengan modal relatif bervariasi yang berusaha di bidang produksi dan penjualan barang atau jasa-jasa untuk memenuhi kebutuhan kelompok masyarakat. $^{27}$

\section{Produk Dagangan}

Produk adalah unsur terpanting dalam kegiatan perdagangan, sebab dengan adanya produk dagangan kegiatan perdagangan yang dilakukan pedagang tentu akan berjalan sebagaimana mestinya. Oleh karena itu, produk adalah segala sesuatu yang dapat di tawarkan kepada pasar untuk memuasakan kebutuhan dan keinginan.

Sedangkan menurut Keegan produk sebagai Produk adalah sebagi koleksi sifatsifat fisik,jasa dan simbolik yang menghasilkan kepuasan atau manfaat bagi seorang pengguna atau pembeli. ${ }^{28}$ Sedangkan produk baru menurut Simamora merupakan barang dan jasa yang pada dasarnya berbeda dari yang telah di pasarkan sebelumnya oleh perusahan. ${ }^{29}$

Berdasarkan beberapa penjelasan di atas dapatlah dipahami bahwa yang dimaksud dengan produk perdagangan adalah segala sesuatu yang dapat ditawarkan kepada pasar dengan memperoleh keuntungan darinya, sementara bagi pembeli mendapatkan produk-produk yang dibeli baik berupa fisik maupun jasa.

Produk memilik beberapa atribut yang menyertai dan melengkapi produk (karakteristik atribut produk), ${ }^{30}$ yaitu:

\footnotetext{
${ }^{27}$ Fani Damayanti, “Analisis Faktor-faktor yang Mempengaruhi Tinggi Rendahnya Pendapatan Pedagang Kaki Lima", 66.

${ }^{28}$ Warren J. Keegan, Manajemen Pemasaran Global (Jakarta: PT. Prenhallindo, 1996), 115.

${ }^{29}$ Simamora, Basis Pengambilan Keputusan Bisnis (Jakarta: Salemba Empat, 2000), 459.

${ }^{30}$ Philip Kotler dan AB. Susanto, Manajemen Pemasaran di Indonesia, Buku 2
}

a. Harga Produk

Adalah nominal harga produk dalam bentuk nilai jual dan nilai beli sesuai dengan kesepakatan pembeli dan penjual.

b. Merek (branding)

Merek (brand) adalah nama, istilah, tanda, simbol, atau rancangan, atau kombinasi dari semua ini yang dimaksudkan untuk mengidentifikasi produk atau jasa dari satu atau kelompok penjual dan membedakannya dari produk pesaing. Pemberian merek merupakan masalah pokok dalam strategi produk. Pemberian merek itu mahal dan memakan waktu, serta dapat membuat produk itu berhasil atau gagal. Nama merek yang baik dapat menambah keberhasilan yang besar pada produk.

c. Pengemasan (packing)

Pengemasan (packing) adalah kegiatan merancang dan membuat wadah atau pembungkus suatu produk.

d. Kualitas Produk (Product Quality)

Kualitas Produk (Product Quality) adalah kemampuan suatu produk untuk melaksanakan fungsinya meliputi, daya tahan keandalan, ketepatan kemudahan operasi dan perbaikan, serta atribut bernilai lainnya. Untuk meningkatkan kualitas produk perusahaan dapat menerapkan program "Total Quality Manajemen (TQM)". Selain mengurangi kerusakan produk, tujuan pokok kualitas total adalah untuk meningkatkan nilai pelanggan.

Selain itu produk penjulan juga mempunyai beberapa tingkatan-tingkatan didalamnya, yaitu:

a. Produk Inti (Core Product)

Produk inti terdiri dari manfaat inti untuk pemecahan masalah yang dicari konsumen ketika mereka membeli produk atau jasa.

(Jakarta: Salemba Empat dan Pearson Education Asia, 2001), 354. 
b. Produk Aktual (Actual Product)

Seorang perencana produk harus menciptakan produk aktual (actual product) disekitar produk inti. Karakteristik dari produk aktual diantaranya, tingkat kualitas, nama merek, kemasan yang dikombinasikan dengan cermat untuk menyampaikan manfaat inti $^{31}$.

c. Produk Tambahan

Produk tambahan harus diwujudkan dengan menawarkan jasa pelayanan tambahan untuk memuaskan konsumen, misalnya dengan menanggapi dengan baik claim dari konsumen dan melayani konsumen lewat telepon jika konsumen mempunyai masalah atau pertanyaan. $^{32}$

\section{Pelanggan}

Definisi pelanggan (Customer) menurut Griffin definisi itu berasal dari kata "Custom" yang didefinisikan sebagai membuat sesuatu menjadi kebiasaan atau biasa dan mempraktekkan kebiasaan. Pelanggan adalah seseorang yang menjadi terbiasa untuk membeli diri Anda. Kebiasaan itu terbentuk melalui pembelian dan interaksi yang sering selama periode waktu tertentu tanpa adalnya track record. Hubungan yang kuat dan pembelian berulang orang tersebut bukanlah pelanggan. ia adalah pembeli. Pelanggan yang sejati tumbuh seiring dengan waktu. ${ }^{33}$

Beberapa perusahan memiliki kepercayaan bahwa mereka dapat mengundang kesetiaan pelanggan dengan cara menawarkan program pemberian penghargaan bagi kesetiaan. Sebuah program kesetiaan dapat menjadi kelengkapan yang baik sebagai bagian dari suatu program pengelolaan hubungan

\footnotetext{
${ }^{31}$ Philip Kotler dan AB. Susanto, Manajemen Pemasaran di Indonesia, Buku 2, 348.

${ }^{32}$ Philip Kotler dan AB. Susanto, Manajemen Pemasaran di Indonesia, Buku 2, 349.

${ }^{33}$ Griffin, Customer Loyalty, Edisi Revisi (Jakarta: Erlangga, 2005), 31.
}

pelanggan, namun banyak program kesetiaan sejenis itu tidak menghasilkan kesetiaan. ${ }^{34}$ Jadi, pelanggan itu merupakan kunci dari suksesnya suatu usaha, maka dari itu perlunya menjaga hubungan baik antara produsen dan pelanggan agar tercapainya profitabilitas produsen.

Menurut Griffin mengatakan bahwa banyak perusahaan mengandalkan kepuasan pelanggan sebagai jaminan keberhasilan di kemudian hari tetapi kemudian kecewa mendapati bahwa para pelangganya yang merasa puas dapat berbelanja produk pesaing tanpa ragu-ragu. Sebaliknya loyalitas pelanggan tampaknya merupakan uuran yang lebih diandalkan untuk memprediksi pertumbuhan penjualan dan keuangan. Berbeda dari kepuasan yang merupakan sikap, loyalitas dapat didefinisikan berdasarkan perilaku membeli. Pelanggan yang loyal adalah orang yang (1) Melakukan pembelian berulang secara teratur (2) Membeli atar lini produk dan jasa (3) Merefrensikan kepada orang lain (4) Menunjukkan kekebalan terhadap tarikan dari pesaing. ${ }^{35}$

Pemasar harus berani mencoba memahami sepenurhnya proses pengambilan keputusan pelanggan mulai dari pengalaman kerja, serta mempromosikan produk tersebut. Ada lima tahapan dalam pengambilan keputusan konsumen, ${ }^{36}$ yaitu:

a. Pengenalan masalah (Problem Recognition)

Proses pembelian dimuai ketika pembeli mengenali masalah atau kebutuhan. Untuk para pemasar perlu mengidentifikasikan keadaan yang memicu kebutuhan tertenu, dengan mengumpulkan informasi dari sejumlah konsumen, dengan demikian para pemasar dapat menyusun strategi

${ }^{34}$ Philip Kotler dan AB. Susanto, Manajemen Pemasaran di Indonesia, Buku 2, 112.

${ }^{35}$ Griffin, Customer Loyalty, Edisi Revisi, 31.

${ }^{36}$ Philip Kotler dan AB. Susanto, Manajemen Pemasaran di Indonesia, Buku 2, 208. 
pemasaran yang mampu memicu minat konsumen untuk melakukan pembelian produk

b. Pencarian Informasi

Konsumen yang merangsang kebutuhannya akan terdorong untuk mencari informasi yang lebihbanyak . yang menjadi perhatian utama pemasar adalah sumber-sumber informasi utama yang menjadi acuan konsumen dan pengaruh relatif tiap sumber terhadap keputusan pembelian selanjutnya.

c. Evaluasi alternative

Tidak ada proses evaluasi tunggal sederhana yang digunakan oleh semua konsumen atau oleh satu konsumen dalam semua situasi pembelian. evaluasi didasarkan pada keyakinan dan sikap yang diperloeh dari bertindak dan belajar.

d. Keputusan pembelian

Konsumen bisa mengambil keputusan untuk tidak secara formal mengevaluasi setiap merek, namun faktor yang mengintervensi bisa mempengaruhi keputusan final.

e. Perilaku pasca pembelian

Setelah pembelian, konsumen mungkin mengalami ketidaksesuaian karena memperhatikan fitur-fitur tertentu yang mengganggu atau mendengar hal-hal yang menyenangkan tentang merek lain, dan akan siaga terhadap informasi yang mendukung keputusan nya. Untuk itu para pemasar ahrus memantau kepuasan pasca pembelian, tindakan pasca pembelian dan pemakaian produk pasca pembelian.

Selain itu juga untuk menjadikan pembeli sebagi pelanggan dari produkproduk yang kita jual, hendaknya diperlukan pemahan dari seorang penjual mengenai harapan-harapan pelanggan. Harapan pelanggan terbagi atas 3 bagian, yaitu:

a. Harapan dasar pelanggan, merupakan tingkat terendah dalam model hirarki harapan pelanggan (tingkat 1) dan mencakup performasi minimum yang selalu diasumsikan ada (implict), sehingga apabila karakteristik produk ini hilang, pelanggan akan selalu tidak puas.

b. Harapan tingkat kedua dari pelanggan, mencakup spesifikasi dan kebutuhan yang terdiri dari pilihan-pilihan dan pertukaran produk yang tersedia untuk dipilih oleh pelanggan.

c. Harapan pelanggan tingkat tertinggi, merupakan nilia tambah dari karakteristik dan features yang tidak diketahui sebelumnya oleh pelanggan (harapan tersembunyi), sehingga apabila karakteristik ini ada pada produk itu, maka pelanggan akan sangat senang atau gembira. ${ }^{37}$

Berdasarkan penjelasan di atas dapatlah kemudian penulis simpulkan bahwa setidak-tidaknya ada empat unsur dalam perdagangan yang saling berkaitan yaitu modal, pedagang, produk, dan pelanggan.

\section{KESIMPULAN}

Setelah melakukan penelitian, penelaahan dan analisis mendalam terhadap data-data hasil penelitian, dapat disimpulkan penelitian sebagai berikut, yaitu pertama, konsistensi pedagang lesehean kesepuhan dalam mempertahankan cita rasa dan harga produk yang diciptakannya dipengaruhi oleh faktor intristik pedagang dan ekstrinsik pedagang, faktor instrinstik pedagang berkaitan dengan ide penentuan produk yang dijual, sementara faktor ekstrinsik pedagang berkaitan dengan konsistensi pedagang dalam membuat resep produk dan soal naik turunya harga pada produk-produk yang dijual oleh pedagang lesehan Kesepuhan Kota Cirebon.

Dan kedua, daya saing pedagagang lesehan Kesepuhan dengan rumah makan di Kota Cirebon terbilang baik karena demi untuk dapat bersaing dengan pedagang yang sudah memiliki tempat permanen, pedagang

${ }^{37}$ Nasution, Manajemen Jasa Terpadu (Jakarta: PT Ghalia, 2004), 19. 
lesehan di kesepuhan melakukan persaingan usaha dengan normal yaitu dengan cara memperkokoh pangsa pasar, menghubungkan dengan lingkungan, meningkatkan kinerja, dan menegakan posisi yang menguntungkan.

\section{DAFTAR PUSTAKA}

AM., Sardiman. Interaksi dan Motivasi Belajar Mengajar. Jakarta: Raja Grafindo. Persada, 1996.

Arianto, Tulus. "Struktur kepemilikan, profitablitas, pertumbuhan aktiva, dan ukuran perusahaan terhadap struktur modal pada perusahaan manufaktur". Jurnal Keuangan dan Perbankan, Vol 12, No. 1 (2008).

Arianto, Tulus. "Struktur Kepemilikan, Profitablitas, Pertumbuhan Aktiva, dan Ukuran Perusahaan terhadap Struktur Modal pada Perusahaan Manufaktur", Jurnal Keuangan dan Perbankan, Vol. 12, No. 1 (2008).

Damayanti, Fani. "Analisis Faktor-faktor yang Mempengaruhi Tinggi Rendahnya Pendapatan Pedagang Kaki Lima", Skripsi. Surakarta: Fakultas Ekonomi Universitas Sebelas Maret, 2011.

David, Fred R. Manajemen Strategis Konep. Jakarta: Salemba Empat, 2011.

Griffin. Customer Loyalty, Edisi Revisi. Jakarta: Erlangga, 2005.

Hasan, Iqbal. Pokok-pokok Materi Metodologi Penelitian dan Aplikasinya. Bogor: Ghalia Indonesia, 2002.

https://kbbi.web.id/

Keegan, Warren J. Manajemen Pemasaran Global. Jakarta: PT. Prenhallindo, 1996.

Kotler, Philip dan AB. Susanto, Manajemen Pemasaran di Indonesia, Buku 2. Jakarta: Salemba Empat dan Pearson Education Asia, 2001.

Kuncoro, Mudrajat. Ekonomika Industri Indonesia: Menuju Negara Industri Baru 2030? Yogjakarta: Penerbit Andi, 2007.
. Otonomi dan Pembangunan Daerah: Reformasi Perencanaan, Strategi, dan Peluang. Jakarta, Penerbit Erlangga, 2004.

Nasution. Manajemen Jasa Terpadu. Jakarta: PT Ghalia, 2004.

Peraturan Menteri Pendidikan Nasional No. 41 Tahun 2007 tentang Standar Proses

Porter, Micel E. Competitive Advantage, Edisi 4. Jakarta: PT. Indeks Kelompok Gramedia, 2001.

Raco, JR. Metode Penelitian Kualitatif, Jenis, Karakteristik dan Keunggulannya. Jakarta: PT. Grasindo, 2010.

Sanjaya, Wina. Perencanaan dan Desain Sistem Pembelajaran. Jakarta: Kencana Prenada Media Group, 2008.

Santoso, Slamet. "Kemampuan Bertahan Pedagang Warung HIK di Kota Ponorogo", Skripsi. Ponorogo: Fakultas Ekonomi Universitas Muhammadiyah, 2006.

Simamora. Basis Pengambilan Keputusan Bisnis. Jakarta: Salemba Empat, 2000.

Sugiono. Metodologi Penelitian Bisnis. Bandung: Alfabeta, 2013.

Suhartanto, dan Nuralia. "Citra Supermarket: Pengaruhnya terhadap Perilaku Konsumen", Jurnal Kajian Bisnis, No. 23 (Agustus, 2001).

Sutopo, HB. Metodologi Penelitian Kualitatif: Dasar Teori dan Terapannya dalam Penelitian. Surakarta: Universitas Sebelas Maret, 2006.

Tambunan, Tulus. Perekonomian Indonesia: Teori dan Temuan Empiris. Jakarta: Ghalia Indonesia, 2001. 